\title{
Performance of Novel Contact Stabilization Activated Sludge System on Domestic Wastewater Treatment ${ }^{1}$ Desempeño de una nueva configuración del sistema de estabilización por contacto en el tratamiento de agua residual doméstica ${ }^{2}$
}

\author{
Andrés Felipe Torres Franco ${ }^{3}$ \\ Nancy Vásquez Sarria ${ }^{4}$ \\ Jenny Alexandra Rodríguez Victoria ${ }^{5}$
}

doi:10.11144/Javeriana.iyu19-2.pncs

How to cite this article:

A.F. Torres Franco, N. Vásquez Sarria, and J.A. Rodríguez Victoria, "Performance of novel contact stabilization activated sludge system or domestic wastewater treatment". Ing. Unv., vol. 19, no. 2, pp. 253-266, 2015. http://dx.doi.org/10.1114/ javeriana.iyul9-2.pncs

\footnotetext{
'Submitted on: December $11^{\text {th }}, 2013$. Acceptance on: January 29, 2015 . This article is derived from the research project Carbon and nitrogen removal in a contact stabilization activated sludge system supported by Universidad del Valle (Colombia) and The International Foundation for science IFS (Sweden), developed by the research group Estudio y Control de la Contaminación Ambiental from Universidad del Valle, Cali, Colombia.

${ }^{2}$ Fecha de recepción: 11 de diciembre de 2013. Fecha de aceptación: 29 de enero de 2015. Este artículo se deriva del proyecto de investigación denominado Reducción de materia orgánica carbonácea y nitrogenada en un sistema de lodos activados en la modalidad de estabilización por contacto financiado por la Universidad del Valle (Colombia) y la Fundación Internacional para la Ciencia IFS(Suecia), desarrollado por el grupo de investigación Estudio y Control de la Contaminación Ambiental de la Universidad del Valle, Cali, Colombia.

${ }^{3}$ Ingeniero sanitario. Magister en Ingeniería, Universidad del Valle, Colombia. E-mail: anfetorres@gmail.com

${ }^{4}$ Ingeniera sanitaria. Doctora en Ingeniería, Universidad del Valle, Colombia. E-mail: navasari@yahoo.com.mx

${ }^{5}$ Ingeniera sanitaria, Dra. Profesora Asociada, Facultad de Ingeniería, Universidad del Valle, Cali, Colombia. E-mail: jenny.rodriguez@correounivalle.edu.co
} 


\section{Abstract}

A pilot-scale study was conducted to evaluate a traditional contact stabilization activated sludge system $\left(\mathrm{CSAS}_{\mathrm{C}}\right)$ and a modified CSAS $\left(\right.$ CSAS $\left._{\mathrm{M}}\right)$ treating domestic wastewater. The $\mathrm{CSAS}_{\mathrm{C}}$ system was comprised of a contact reactor $(C R)$, a stabilization reactor $(S R)$ and a secondary settler $(S S)$; the $\mathrm{CSAS}_{\mathrm{M}}$ included a second $C R$, a second $\mathrm{SS}\left(C R_{2}\right.$ and $\left.S S_{2}\right)$, and a modified $S R\left(S R_{M}\right)$ divided into four zones: an attached-suspended growth zone which allowed the system to reach an average sludge retention time close to $36 \mathrm{~d}$ and favored the occurrence of nitrification; an anoxic zone for denitrification occurrence; an aerated suspended growth zone with a high presence of organic carbon; and an additional aerated suspended growth zone with a high ammonia concentrations environment. The $\mathrm{CSAS}_{\mathrm{C}}$ 's removal efficiencies of chemical oxygen demand (COD) and total ammonia nitrogen (TAN) were respectively $94 \pm 4 \%$ and $53 \pm 12 \%$; whereas $\mathrm{CSAS}_{\mathrm{M}}$ 's efficiencies were $88 \pm 7 \%$ for COD and $92 \pm 7 \%$ for TAN. Concentrations of TAN and $\mathrm{NO}_{3}{ }^{-} \mathrm{N}$ in the CSAS ${ }_{\mathrm{C}}$ 's final effluent were 14.3 \pm 5.2 and $5.0 \pm 2.9 \mathrm{mg} \times \mathrm{L}^{-1}$; and $4.8 \pm 4.4$ and $9.1 \pm 5.8 \mathrm{mg} \times \mathrm{L}^{-1}$ in the CSAS $_{\mathrm{M}}$ 's final effluent. Results demonstrated that the proposed configuration obtained higher nitrogen removal efficiencies than traditional CSAS.

\section{Keywords}

activated sludge; contact stabilization; organic carbon; nitrogen removal; domestic wastewater

\section{Resumen}

Usando una prueba a escala piloto se evaluó un sistema de estabilización por contacto convencional $\left(\mathrm{CSAS}_{\mathrm{C}}\right)$ y uno modificado $\left(\mathrm{CSAS}_{\mathrm{M}}\right)$, para el tratamiento de agua residual doméstica. El CSAS $_{\mathrm{C}}$ estuvo compuesto de un reactor de contacto $(C R)$, un reactor de estabilización $(S R)$ y un sedimentador secundario (SS); el CSAS ${ }_{\mathrm{M}}$ incluyó la adición de un SR y un $\mathrm{SS}\left(C R_{2}\right.$ y $\left.S S_{2}\right)$ y la modificación del reactor de estabilización $\left(S R_{M}\right)$, en cuatro zonas: una de crecimiento adherido-suspendido, que permitió alcanzar un tiempo de retención celular promedio cercano a $36 \mathrm{~d}$ y que beneficia el desarrollo de la nitrificación; una zona anóxica para el desarrollo de la denitrificación; una zona aireada de crecimiento suspendido, con un ambiente rico en materia orgánica carbonácea, y otra con un ambiente rico en nitrógeno amoniacal total (NAT). El CSAS ${ }_{\mathrm{C}}$ presentó eficiencias de reducción de química de oxígeno (DQO) y NAT de $94 \pm 4 \%$ y $53 \pm 12 \%$ respectivamente; mientras que el CSAS ${ }_{\mathrm{M}}$ presentó eficiencias del $88 \pm 7 \%$, y de $92 \pm 7 \%$, respectivamente. Las concentraciones promedio de NAT y N-NO${ }_{3}{ }^{-}$en el efluente del $\mathrm{CSAS}_{\mathrm{C}}$ fueron de $14,3 \pm 5,2$ y $5,0 \pm 2,9 \mathrm{mg} \times \mathrm{L}^{-1}$, respectivamente, y para el CSAS ${ }_{\mathrm{M}}$ fueron de $4,8 \pm 4,4$ y $9,1 \pm 5,8 \mathrm{mg} \times \mathrm{L}^{-1}$, respectivamente. Estos resultados demostraron que la nueva configuración evaluada presentó mayores eficiencias de reducción de material nitrogenado.

\section{Palabras clave}

lodos activados; estabilización por contacto; materia orgánica carbonácea; remoción de nitrógeno; agua residual doméstica 


\section{Introduction}

Municipal wastewater contains a variety of organic compounds of carbon and nitrogen. Nitrogen material is related not only to organic forms, but to inorganic forms, especially $\mathrm{NH}_{4}^{+}-\mathrm{N}$. High nitrogen concentrations in wastewater are associated with eutrophication, which affects freshwater quality. In consequence, conventional wastewater treatment plants aim to reduce concentrations of such compounds in final effluent through secondary and tertiary treatment processes.

Contact Stabilization Activated Sludge system (CSAS) is a variation of the conventional activated sludge system (Figure 1a), where two aerated tanks and a secondary settler are used to remove carbonaceous material concentrations incoming with influent wastewater. The process begins in the Contact Reactor $(C R)$, where influent wastewater is mixed with recirculation sludge from the Stabilization Reactor $(S R)$ to conform the mixed liquor $(M L)$. After a short hydraulic retention time (HRT) in the CR, the ML is conduced to the Secondary Settler (SS), where separation of clarified effluent and sludge occurs. Separated sludge is recirculated to $S R$ to start the process again after a HRT of $2-8 \mathrm{~h}$. The process' conceptual base is to optimize adsorption of carbonaceous material over the floc structure during $C R$ 's HRT, which ranges between 0.5-1.5 h, whereas $S R$ is conceived with a longer HRT to metabolize in there substrates previously adhered to floc structure [1]-[3].

Different experiences have demonstrated the excellent performance of CSAS, with COD removal efficiencies almost always higher than $80 \%$ [4], [5], and even higher than $90 \%$ for $\mathrm{BOD}_{5}$ [1]. CSAS has been also used as a high-load process for maximizing sludge production in domestic wastewater pretreatment, obtaining COD removal efficiencies of 66 $5 \%$ [6]. Nevertheless, even though nitrogen transformations are not intended to occur in CSAS, Alexander $e t$ al. [7] documented that a Sludge Retention Time (SRT) longer than 4d and high Recirculation Rates (R) favored nitrogen transformations in CSAS systems, whereas other papers have documented nitrification percentages in CSAS systems 
of $25 \%$ [5], 70\% [4], and 77\% [2]. Furthermore, denitrification, ammonification, and denitrification can take place in small proportions in CSAS systems [2], [4]. Sludge Retention Time (SRT ${ }_{C}$ ) is then a decisive variable to design and control CSAS systems. Eq. 1 shows the expression defined by Alexander $e t a l$. [7] for SRT estimation:

$$
S R T=\frac{\text { mass of sludge in the process }}{\text { mass of sludged wasted per day }}=\frac{X_{C R} V_{C R}+X_{S R} V_{S R}}{X_{S R} Q_{W}}
$$

Where:

$\mathrm{X}_{\mathrm{SR}}$ : Volatile suspended solids in the sludge wasted from SR, $\mathrm{mgVSS} \times \mathrm{L}^{-1}$ $\mathrm{Q}_{\mathrm{W}}$ : Waste flow $\left({\left.\mathrm{L} . \mathrm{d}^{-1}\right)}^{-1}\right.$

The occurrence of nitrogen transformations in CSAS systems suggest that some modifications could be made to improve nitrogen removal without affecting organic carbon removal efficiencies. Anoxic zones with presence of high organic carbon concentrations can incentivize denitrification if there is an entrance of nitrate coming from nitrification in the SR, which can be stimulated trough hybrid suspended-attached systems [8]-[10]. Currently, recent works in CSAS have proposed system modifications to improve phosphorus removal [11], but no research has been carried out for a nitrogen removal optimization. Considering this background, this study evaluated a $\mathrm{CSAS}_{\mathrm{C}}$ system and a $\mathrm{CSAS}_{\mathrm{M}}$ in order to evaluate nitrogen removal efficiencies.

\section{Materials and Methods}

\subsection{Experimental Unit}

The CSAS system presented a typical configuration conformed by a contact reactor (CR), a stabilization reactor (SR), and a secondary settler (SS) (Figure 1a). The CSAS $_{\mathrm{M}}$ (Figure 1b) was divided into two stages: The first stage (Stage 1) was primary conceived for carbonaceous matter removal and included $C R_{1}+\left(S S_{1}+S R_{1+2}\right)$, whereas the main purpose of the second stage (Stage 2) was nitrogen removal and included $C R_{2}+\left(S S_{2}+S R_{3+4}\right)$. The stabilization reactor was a unique unit with different compartments that could be described as follows: i) $\mathrm{SR}_{1}$ an aerated zone of suspended growth with a high presence of organic carbon; ii) $\mathrm{SR}_{2}$ an anoxic zone which favored denitrification; iii) $\mathrm{SR}_{3}$ an attached-suspended growth zone 
which favored nitrification and denitrification; and finally, iv) $\mathrm{SR}_{4}$ an additional aerated zone of suspended growth with a high ammonia concentrations measured as total ammonia nitrogen (TAN) for favored nitrification. The volumes of the treatment unit were $9.98 \mathrm{~L}$ for $C R_{1}, 36.68 \mathrm{~L}$ for $C R_{2}, 27.20$ for $S R_{1}, 8.90 \mathrm{~L}$ for $S R_{2}, 8.75$ for $S R_{3}$, and $8.75 \mathrm{~L}$ for $S R_{4}$. Units were constructed on glass fiber and peristaltic pumps were used for recirculation lines. Aeration in $C R_{1}, C R_{2}, S R_{1}$, and $S R_{4}$ was supplied with a blower and bubble diffusers.

Figure 1. (a) CSAS,'s and (b) CSAS 'S configuration

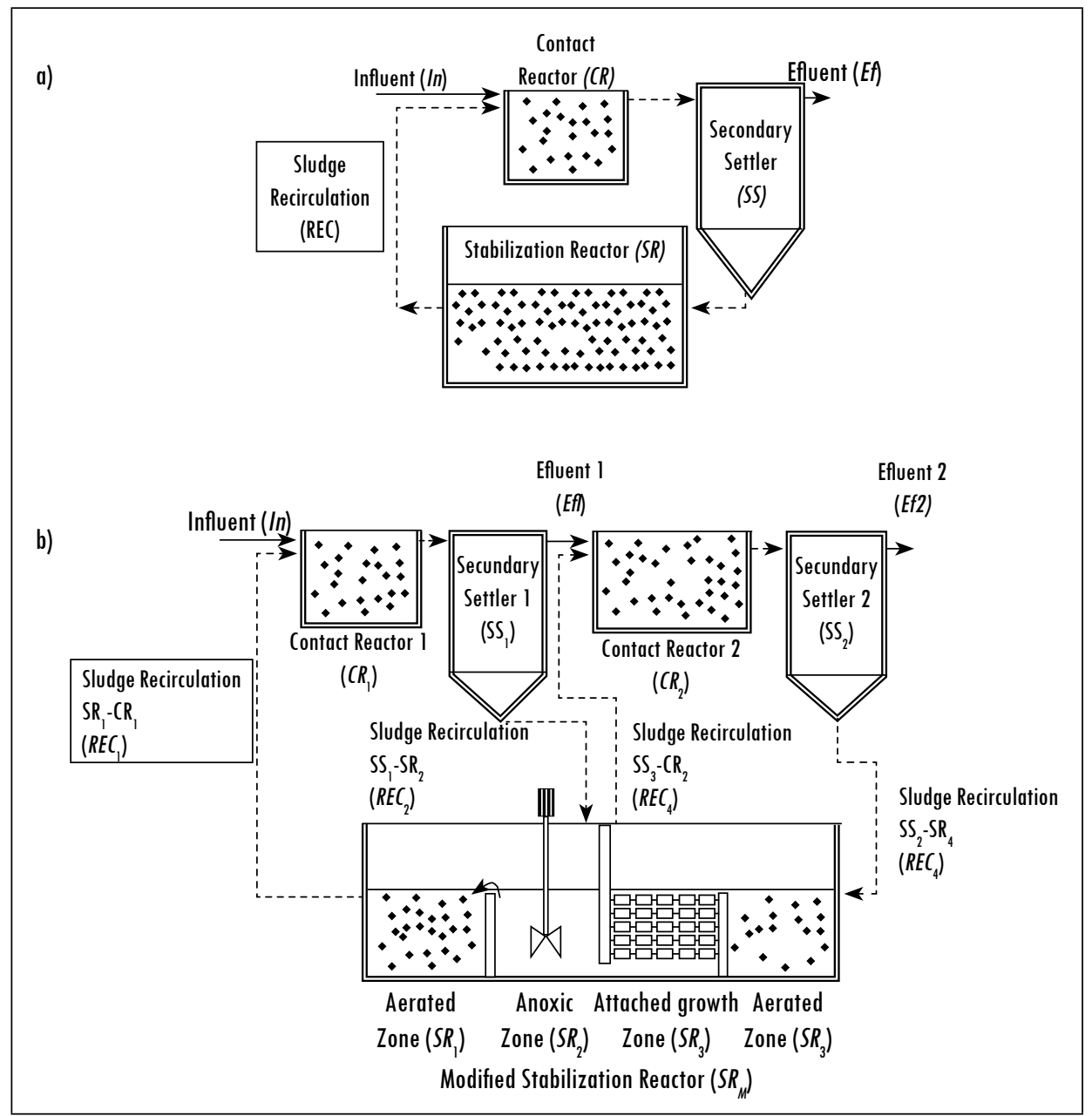

Source: author's own elaboration 
Waste Sludge from real-scale "Aguas del Sur" wastewater treatment plant (WWTP) was used for the inoculation of the systems. CSAS ${ }_{\mathrm{C}}$ start-up phase was performed during $10 \mathrm{~d}$ through progressive affluent flow increments, from $50 \%$ to $100 \%$. Those increments were conditioned to COD removal efficiencies higher than $60 \%$. Once CSAS $_{C}$ operation period was completed, the CSAS $_{M}$ start-up phase was begun. Inoculum acclimation and start-up phase were performed during $15 \mathrm{~d}$. After this period, $S R_{3+4}$ (separated from $S_{1+2}$ through a division screen) and $S S_{2}$ were added as a second CSAS for CSAS 's effluent posttreatment. After an additional $17 \mathrm{~d}$, the division screen was removed, the four zones inside $\mathrm{SR}_{\mathrm{M}}$ were established and the $\mathrm{CSAS}_{\mathrm{M}}$ evaluation period was started. System's influent (In) was taken from "Aguas del Sur" WWTP, after screening and then conduced to a primary clarifier with a HRT of $1 \mathrm{~h}$.

\subsection{System Control and Evaluation}

Samples from mixed liquors, Influent (In), and effluent of $\operatorname{CSAS}_{C}(E f)$ and $\mathrm{CSAS}_{\mathrm{M}}\left(E f_{2}\right)$ were taken twice a week. COD, TAN, nitrates $\left(\mathrm{NO}_{3}^{-}-\mathrm{N}\right)$, phosphorus $\left(\mathrm{PO}_{4}{ }^{3}-\mathrm{P}\right), \mathrm{pH}$, and total and bicarbonate alkalinity were measured for influent characterization. Volatile suspended solids (VSSML), $\mathrm{pH}$, and dissolved oxygen (DO) were measured in mixed liquors of $C R$ and $S R$ in $C S A S_{C}$, and $C R_{1}$, $C R_{2}, S R_{1}, S R_{2}, S R_{3}$, and $S R_{4}$ in $\mathrm{CSAS}_{\mathrm{M}}$. In order to operate $\mathrm{CSAS}_{\mathrm{C}}$ and $\mathrm{CSAS}_{\mathrm{M}}$, VSSLM, DO, $\mathrm{pH}$, temperature, food-microorganisms ratio $(\mathrm{F} / \mathrm{M})$, and SRT were monitored. COD and TAN removal efficiencies were estimated from influent and effluents concentrations, where $\mathrm{NO}_{3}^{-}-\mathrm{N}$ and alkalinity were also measured. All parameters were determined as indicated by [12].

Operational conditions evaluated in $\mathrm{CSAS}_{\mathrm{C}}$ and $\mathrm{CSAS}_{\mathrm{M}}$ during the operation were chosen from previous studies in CSAS systems. A SRT range between 6-10 d was chosen to secure nitrification. $\mathrm{HRT}_{\mathrm{CR}}$ of $0.84 \mathrm{~h}, \mathrm{HRT}_{\mathrm{SR}}$ of $4.10 \mathrm{~h}$, $\mathrm{VSSML}_{\mathrm{CR}}$ of $1000 \mathrm{mg} \times \mathrm{L}^{-1}$, and $\mathrm{VSSML}_{\mathrm{SR}}$ of $2000 \mathrm{mg} \times \mathrm{L}^{-1}$, DO concentration of $4.0 \mathrm{mg} \times \mathrm{L}^{-1}[2],[5],[7]$. Wasted sludge was taken from $S R$ and $\mathrm{SR}_{1}$ in $\mathrm{CSAS}_{\mathrm{C}}$ and $\mathrm{CSAS}_{\mathrm{M}}$ respectively. Sludge retention time for $\mathrm{CSAS}_{\mathrm{C}}\left(\mathrm{SRT}_{\mathrm{C}}\right)$ was evaluated according to Eq. 2, according to solids flow in the $\mathrm{CSAS}_{\mathrm{M}}$, although a global SRT (SRT $\mathrm{M}_{\mathrm{M}-\mathrm{G}}$ ) was totalized as shown before in Eq. 1; an internal SRT was also established for each stage. For Stage 1 suspended biomass in $C R_{1}, S R_{1}$, and $S R_{2}$ and sludge wasted from $S R_{1}$ define the $S R T_{\mathrm{M}-\mathrm{S} 1}$ as expressed in Eq. 2.

$T R C_{M-S 1}=\frac{\text { Biomass in Stage } 1}{\text { Biomass leaving Stage } 1}=\frac{V_{C R 1} X_{C R 1}+V_{S R 1} X_{S R 1}+V_{S R 2} X_{S R 2}}{Q_{E F 1} X_{E F 1}+Q_{W S R 1} X_{S R 1}+S_{1}}$ (Eq. 2) 
Where:

$\mathrm{S}_{1}$ : $\quad$ biomass sampled from Stage 1

$S_{1}: \quad Q_{M, C R 1} * X_{C R 1}+Q_{M, S R 1} * X_{S R 1}+Q_{M, S R 2} * X_{S R 2}$

$\mathrm{Q}_{\mathrm{M}}: \quad \mathrm{Q}_{\text {sampled }}$ in each reactor $\left(\mathrm{L} \times \mathrm{d}^{-1}\right)$

$\mathrm{Q}_{\mathrm{W}, \mathrm{SR} 1}$ : Sludge waste flow from $\mathrm{SR}_{1}\left(\mathrm{~L} \times \mathrm{d}^{-1}\right)$

For Stage 2 suspended biomass in $\mathrm{CR}_{2}, \mathrm{SR}_{3}$, and $\mathrm{SR}_{4}$ and attached biomass in $\mathrm{SR}_{3}$ were considered to define $\mathrm{SRT}_{\mathrm{M}-\mathrm{S} 2}$ (Eq. 3). According to CSAS $\mathrm{M}_{\mathrm{M}}$ configuration of SRT ${ }_{M}$ was defined as presented in Eq. 3, by considering attached and suspended biomass. Attached biomass was estimated using the mathematical model of Rittmann and McCarty [13] for attached biomass growth $\left(a \mathrm{VJYb}_{t}{ }^{-1}\right)$, which has been employed in different works related with attached-suspended reactors [14], [15], [10]. Kinetic parameters registered in Table 1 and simplified expressions proposed by Fouad and Barghava [15] were used to estimate $a \mathrm{VJY}_{\mathrm{t}}^{-1}$. According to low $\mathrm{C} / \mathrm{N}$ conditions in $S R_{3}$, ammonia oxidizing bacteria (AOB) predominated in attached growth and consequently, kinetic constants from AOB were employed to estimate $a \mathrm{VJYb}_{t}^{-1}$. Values in Table 1 were taken from references where a particular estimation of each constant was made, similar physicochemical conditions to $\mathrm{SR}_{3}$ predominated, and low density polyurethane was employed for attached growth. Finally, for the estimation of SRT $\mathrm{M}_{\mathrm{M}-\mathrm{S} 2}$ it was considered that sludge flow from $\mathrm{SR}_{3}$ to $S R_{4}$ constituted a sludge waste from Stage 2. Attached biomass concentration $\left(\mathrm{X}_{\mathrm{f}}\right)$ was estimated by separating it from media using a Stomacher $400 \mathrm{~mL}$ Bagmixer-400W Interscience $\AA$, at 7 strokes for 60 s. Separated biomass was diluted

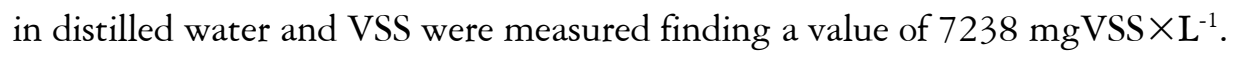

$$
\begin{aligned}
T R C_{M-S 2}= & \frac{\text { Biomass in } S_{2}}{\text { Biomass leaving } S_{2}}=\frac{\text { Suspended biomass }+ \text { attached biomass }}{\text { Biomass leaving } S_{2}} \\
= & \frac{V_{C R 2} X_{C R 2}+V_{S R 3} X_{S R 3}+V_{S R 4} X_{S R 4}+a V J \frac{Y}{b_{t}}}{Q_{E F 2} X_{E F 2}+Q_{W}{ }_{S R 3} X_{S R 3}+S_{2}}
\end{aligned}
$$

Where:

$\mathrm{s}_{2}$ : $\quad$ biomass sampled from Stage 2

$s_{2}: \quad\left(Q_{M C R 2} \times X_{C R 2}\right)+\left(Q_{M S R 3} \times X_{S R 3}\right)+\left(Q_{M S R 4} \times X_{S R 4}\right)$

$\mathrm{Q}_{\mathrm{W}, \mathrm{SR} 3}: \quad$ Sludge flow from $S R_{3}$ to $S R_{2}\left(\mathrm{~L}^{\mathrm{d}} \mathrm{d}^{-1}\right)$

$\mathrm{VVJYb}_{\mathrm{t}}^{-1}$ : Attached biomass expression 
Table 1. Kinetic and stoichiometric parameters selected for $\mathrm{aVJYb}_{+}^{-1}$ estimation

\begin{tabular}{|c|c|c|c|c|}
\hline Parameter & Notation & Value & Units & References \\
\hline TAN half saturation coefficient & $\mathrm{K}_{\mathrm{TAN}}$ & 1.47 & $\operatorname{mgTAN} \times \mathrm{L}^{-1}$ & Grady et al. [16] \\
\hline $\begin{array}{l}\text { Maximum specific rate of TAN } \\
\text { utilization }\end{array}$ & $\mathrm{k}_{\mathrm{TAN}}$ & 3.80 & $\mathrm{~d}^{-1}$ & $\operatorname{Lin}[17]$ \\
\hline Yield coefficient & $\mathrm{Y}_{\mathrm{AOB}}$ & 0.33 & $\begin{array}{l}\operatorname{mgVSS} \times \\
\left(\mathrm{mgNH}_{4}^{+}-\mathrm{N}\right)^{-1}\end{array}$ & $\begin{array}{l}\text { Ritmann and } \\
\text { McCarty [13] }\end{array}$ \\
\hline Specific decay rate & $\mathrm{k}_{\mathrm{d}}$ & 0.15 & $d^{-1}$ & $\begin{array}{l}\text { Spanjers and } \\
\text { Vanrrolleguem } \\
{[18]}\end{array}$ \\
\hline Specific shear loss rates & $\mathrm{b}_{\mathrm{s}}$ & $1 \times 10^{-4}$ & $d^{-1}$ & $\operatorname{Lin}[17]$ \\
\hline $\begin{array}{l}\text { Molecular } \\
\text { diffusion coefficient in the } \\
\text { biofilm }\end{array}$ & $D_{f}$ & 1.382 & $\mathrm{~cm}^{2} \cdot \mathrm{d}^{-1}$ & $\operatorname{Lin}[17]$ \\
\hline $\begin{array}{l}\text { Molecular diffusion coefficient } \\
\text { in water }\end{array}$ & $\mathrm{D}_{\mathrm{w}}$ & 1.300 & $\mathrm{~cm}^{2} \cdot \mathrm{d}^{-1}$ & $\begin{array}{l}\text { Ritmann and } \\
\text { Manem }[14]\end{array}$ \\
\hline Biofilm layer thickness & $\mathrm{L}(\mathrm{cm})$ & 0.0082 & $\mathrm{~cm}$ & $\operatorname{Lin}[17]$ \\
\hline Polyurethane specific surface area & A & 11.2 & $\mathrm{~cm}^{-1}$ & Feng et al. [19] \\
\hline
\end{tabular}

$\left.(*)^{* *}\right)$ Temperature correction was applied. Temperature in $S R_{3}$ presented a mean value of $27.5^{\circ} \mathrm{C} .{ }^{(*)} \Theta=1,053[20]$. $\mathrm{K}_{\text {TAN }}$ in reference: $1.0 \mathrm{mgTAN} \times \mathrm{L}^{-1}\left(20^{\circ} \mathrm{C}\right) . .^{(* *)} \Theta=1.04[20] . \mathrm{K}_{\mathrm{d}}$ in Reference, $0.11 \mathrm{~d}^{-1}\left(20^{\circ} \mathrm{C}\right)$. Source: author's own elaboration

\section{Results}

\subsection{Influent Characterization}

After primary clarification, influent was transported to the evaluated systems. Previous research has demonstrated that primary clarifiers do not affect influent nitrogen concentrations and have a positive influence on CSAS's performance because they function as a barrier to fats, oils, and surfactants that affect secondary sludge quality [21]. Influent characteristics are presented in Table 2. Influent variation was conditioned by wastewater production dynamic in "Aguas del Sur" WWTP. CSAS ${ }_{M}$ 's influent was more concentrated than CSAS $_{C}$ 's, which was influenced by a rainy season. Measured values for both $\mathrm{CSAS}_{\mathrm{C}}$ and $\mathrm{CSAS}_{\mathrm{M}}$ were according to typical ranges of wastewater produced in Santiago de Cali, and guaranteed carbonaceous organic matter, nutrients, and alkalinity availability for biological processes. No influence of wastewater quality variations was detected 
in the performance of both, $\mathrm{CSAS}_{\mathrm{C}}$ and $\mathrm{CSAS}_{\mathrm{M}}$, and no statistical differences were noted in influent TAN concentration.

Table 2. Influent characterization

\begin{tabular}{|l|l|r|r|}
\hline \multirow{2}{*}{ Parameter } & \multirow{2}{*}{ Units } & \multicolumn{2}{c|}{ Measured Values } \\
\cline { 3 - 4 } & & \multicolumn{1}{|c|}{ CSAS } & CSAS $_{M}$ \\
\hline $\mathrm{COD}$ & $\mathrm{mg} \times \mathrm{L}^{-1}$ & $222.8 \pm 73.7$ & $341.2 \pm 122.6$ \\
\hline $\mathrm{BOD}_{5}$ & $\mathrm{mg} \times \mathrm{L}^{-1}$ & $124.7 \pm 71.5$ & $192.1 \pm 56.5$ \\
\hline $\mathrm{TAN}$ & $\mathrm{mg} \times \mathrm{L}^{-1}$ & $34.7 \pm 6.6$ & $48.9 \pm 9.0$ \\
\hline $\mathrm{NO}_{3}{ }^{-}-\mathrm{N}$ & $\mathrm{mg} \times \mathrm{L}^{-1}$ & $0.21 \pm 0.30$ & $1.1 \pm 0.8$ \\
\hline $\mathrm{PO}_{4}{ }^{3}-\mathrm{P}$ & $\mathrm{mg} \times \mathrm{L}^{-1}$ & $5.7 \pm 1.1$ & $9.3 \pm 1.5$ \\
\hline $\mathrm{Bicarbonatic} \mathrm{alkalinity}^{*}$ & $\mathrm{mgCaCO} \times \mathrm{L}^{-1}$ & $119.7 \pm 24.2$ & $203.0 \pm 36.7$ \\
\hline Total alkalinity & $\mathrm{mgCaCO}{ }_{3} \times \mathrm{L}^{-1}$ & $160.0 \pm 31.5$ & $303.9 \pm 32.0$ \\
\hline TSS & $\mathrm{mg} \times \mathrm{L}^{-1}$ & $51.5 \pm 19.7$ & $80.8 \pm 63.0$ \\
\hline $\mathrm{pH}$ & $\mathrm{unid}$ & $6.30 \mathrm{a} 7.20$ & $6.45-7.54$ \\
\hline
\end{tabular}

Source: author's own elaboration

\subsection{System Performance and Nitrogen Removal}

Operational conditions in $\mathrm{CSAS}_{\mathrm{C}}$ and $\mathrm{CSAS}_{\mathrm{M}}$ are registered in Table 3. Obtained values were according referenced values for CSAS systems where nitrification took place. Additionally, temperature and $\mathrm{pH}$ ranges were optimum for nitrification occurrence ( $\mathrm{pH}: 7.5$ - 8.0 units, $\mathrm{T}: 28-36{ }^{\circ} \mathrm{C}$ [22]).

Table 3. Operational conditions

\begin{tabular}{|c|c|c|c|c|c|c|}
\hline System & Reactor & HRT (h) & $\mathrm{pH}$ (unit) & $\mathrm{T}\left({ }^{\circ} \mathrm{C}\right)$ & $\operatorname{VSSML}\left(\mathrm{mg} \times \mathrm{L}^{-1}\right)$ & $\mathrm{DO}\left(\mathrm{mg} \times \mathrm{L}^{-1}\right)$ \\
\hline \multirow{2}{*}{$\begin{array}{l}\text { CSAS } \\
\text { REC }=100 \%\end{array}$} & CR & 0.84 & $7.1-7.8$ & $28.2 \pm 2.0$ & $1498 \pm 350$ & $3.2 \pm 1.2$ \\
\hline & SR & 4.02 & $6.7-7.6$ & $28.3 \pm 1.9$ & $3588 \pm 726$ & $2.1 \pm 1.4$ \\
\hline \multirow{6}{*}{$\begin{array}{l}\operatorname{CSAS}_{\mathrm{M}} \\
\mathrm{REC}_{1}=51 \% \\
\mathrm{REC}_{2}=50 \% \\
\mathrm{REC}_{3}=98 \% \\
\mathrm{REC}_{4}=100 \%\end{array}$} & $\mathrm{CR}_{1}$ & 0.83 & $6.2-8.1$ & $26.5 \pm 1.5$ & $1243 \pm 412$ & $3.0 \pm 1.7$ \\
\hline & $\mathrm{CR}_{2}$ & 3.03 & $5.5-7.7$ & $26.2 \pm 1.7$ & $1393 \pm 523$ & $3.3 \pm 1.6$ \\
\hline & $\mathrm{SR}_{1}$ & 4.43 & $5.7-7.7$ & $26.6 \pm 1.7$ & $2448 \pm 1160$ & $3.1 \pm 1.7$ \\
\hline & $\mathrm{SR}_{2}$ & 1.45 & $5.8-7.7$ & $26.6 \pm 1.7$ & $2752 \pm 1083$ & $0.8 \pm 1.1$ \\
\hline & $\mathrm{SR}_{3}$ & 0.73 & $5.8-7.8$ & $26.6 \pm 1.7$ & $2771 \pm 1009$ & $1.9 \pm 1.3$ \\
\hline & $\mathrm{SR}_{4}$ & 0.73 & $5.8-7.8$ & $26.6 \pm 1.7$ & $2638 \pm 1025$ & $1.9 \pm 1.2$ \\
\hline
\end{tabular}

Source: author's own elaboration 
TAN and $\mathrm{NO}_{3}^{-}-\mathrm{N}$ concentrations in final effluent of $\mathrm{CSAS}_{\mathrm{C}}(E f)$ were $14.3 \pm 5.2 \mathrm{mgTAN} \times \mathrm{L}^{-1}$ and $5.0 \pm 2.9 \mathrm{mgNO}_{3}{ }^{-} \mathrm{N} \times \mathrm{L}^{-1}$, whereas concentrations of in $\mathrm{CSAS}_{\mathrm{M}}$ 's final effluent $\left(\mathrm{Ef}_{2}\right)$ were $4.8 \pm 4.4 \mathrm{mgTAN} \times \mathrm{L}^{-1}$ and $9.1 \pm 5.8 \mathrm{mgNO}_{3}{ }^{-}$ $-\mathrm{N} \times \mathrm{L}^{-1}$, respectively. Figure 2 presents the variation in the nitrogen compounds concentrations of the final effluent. TAN removal efficiencies were respectively $53 \pm 12 \%$ and $92 \pm 7 \%$ for traditional $\left(\mathrm{CSAS}_{\mathrm{C}}\right)$ and modified $\left(\mathrm{CSAS}_{\mathrm{M}}\right)$ systems.

Figure 2. Nitrogen variation in CSAS $_{C}$ and $C_{C S} S_{M}$

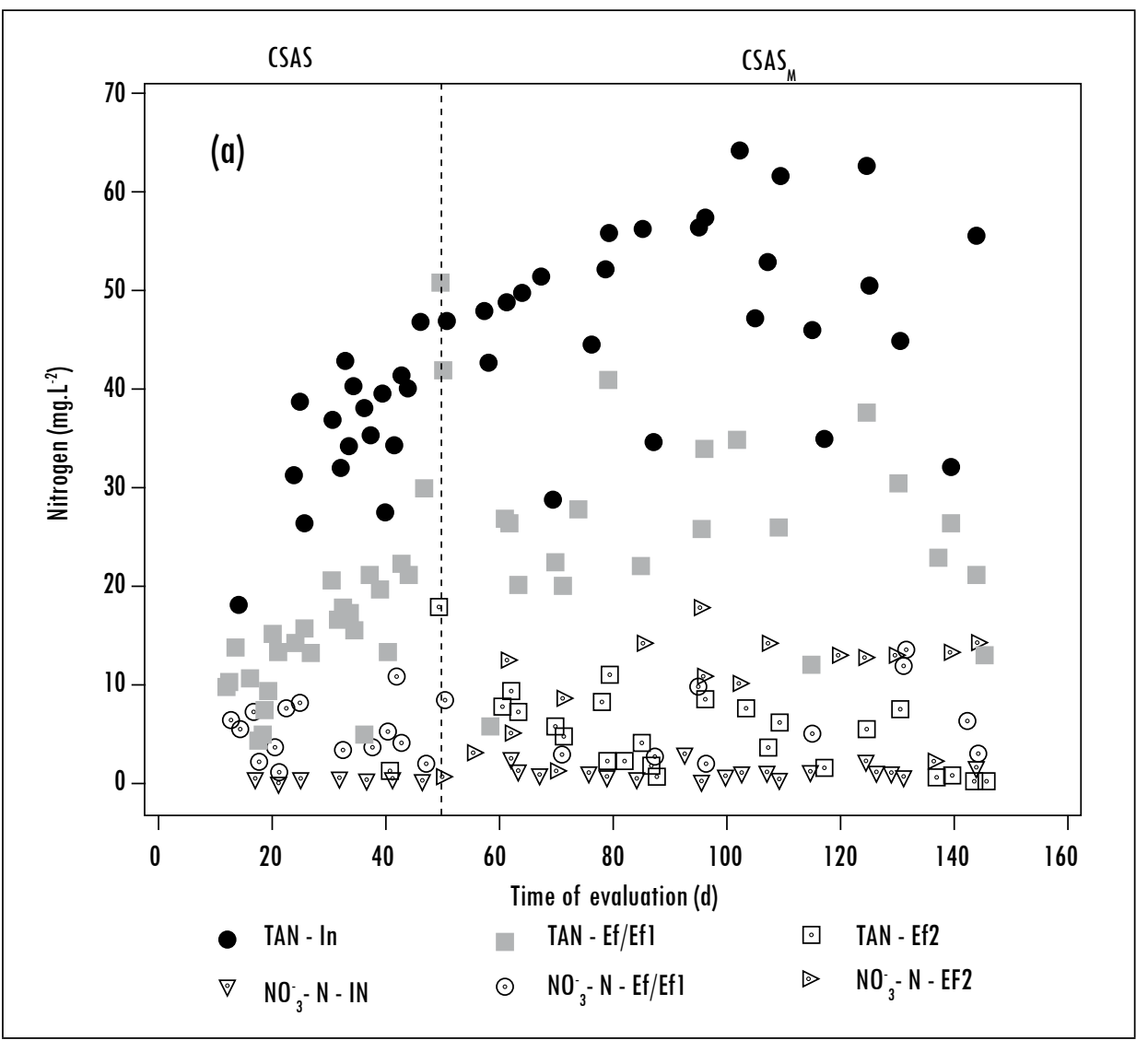




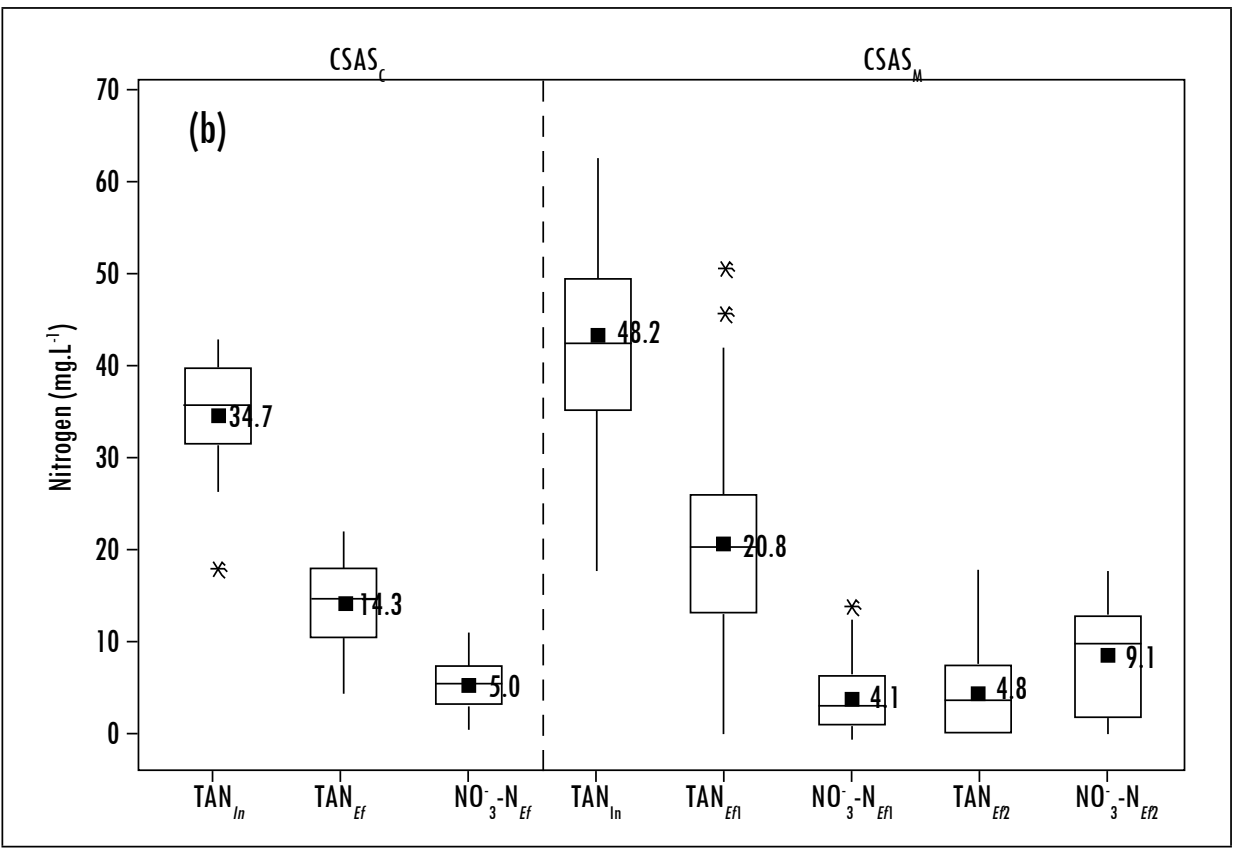

Source: author's own elaboration

TAN removal efficiencies observed in the traditional system $\left(\mathrm{CSAS}_{\mathrm{C}}\right)$ were similar to those previously reported in [1], [4]. Both TAN removal efficiencies and $\mathrm{NO}_{3}^{-}-\mathrm{N}$ concentrations in the final effluent evidenced that nitrification was the main TAN transformation process. Environmental conditions in the contact reactor $(C R)$ and the stabilization reactor $(S R)$ support this idea as an aerobic environment predominated (CR: $3.2 \pm 1.2 \mathrm{mgDO} \times \mathrm{L}^{-1}$ and SR: $2.1 \pm 1.4 \mathrm{mgDO} \times \mathrm{L}^{-1}$ ), inorganic carbon presence supported by total and bicarbonate alkalinity concentrations in influent, and a SRT high enough to enable nitrifier organism growth at process' temperatures. Even when $\mathrm{NO}_{3}^{-}-\mathrm{N}$ concentrations in $\mathrm{CSAS}_{\mathrm{C}}$ 's final effluent $(E f)$ were low, processes of $\mathrm{NO}_{3}-\mathrm{N}$ removal like denitrification could have occurred only in low rates because the environmental conditions in $C R$ and $S R$ were predominantly aerobic, however, a possible presence of anoxic microzones and a complete anoxic environment in the bottom of the SS could have promoted incipient denitrification.

The higher TAN removal efficiencies exhibited by $\mathrm{CSAS}_{\mathrm{M}}$ were related to Stage 2 performance. The establishment of high $\mathrm{SRT}_{\mathrm{M}-\mathrm{S} 2}$ was a consequence of attached growth in $\mathrm{SR}_{3}$, which possibly favored the presence of nitrifiers and distribution in $\mathrm{CSAS}_{\mathrm{M}}$. The measured $\mathrm{SRT}_{\mathrm{M}-\mathrm{S} 2}$ of $20.9 \pm 6.7 \mathrm{~d}$ which increased the $\mathrm{SRT}_{\mathrm{G}}$ values up to $36.2 \pm 14.2 \mathrm{~d}$ are coincident with those reported for 
attached-suspended growth reactors to favor nitrification performance [8], [23], [24]. The high nitrification rates compared with low $\mathrm{NO}_{3}^{-}-\mathrm{N}$ concentrations in $\mathrm{CSAS}_{\mathrm{M}}$ 's final effluent suggest that processes of $\mathrm{NO}_{3}^{-}-\mathrm{N}$ removal actually took place in $\mathrm{CSAS}_{\mathrm{M}}$ at a considerable rate, which is consequent with $S R_{2}$ 's conditions. Low DO concentrations $\left(0.7 \pm 1.0 \mathrm{mg} \times \mathrm{L}^{-1}\right)$ in the anoxic compartment $\left(S R_{2}\right)$ and the permanent entrance of carbonaceous organic matter incoming, with recirculation from $\mathrm{SS}_{1}$ and $\mathrm{NO}_{3}{ }^{-} \mathrm{N}$ from the attached growth compartment $\left(S R_{3}\right)$, suggest that the main process of $\mathrm{NO}_{3}{ }^{-} \mathrm{N}$ removal was denitrification.

An incipient denitrification took place in the bottom of $\mathrm{CSAS}_{\mathrm{M}}$ 's $\mathrm{SS}_{2}$. Some sludge resuspension events are evidence of denitrification in the aforementioned zone. Presence of carbonaceous matter from endogenous metabolism and $\mathrm{NO}_{3}{ }^{-}-\mathrm{N}$ produced in Stage 2, as well as DO absence were conditions that promoted denitrification. Small $\mathrm{N}_{2}$ bubbles produced by denitrification could have risen from the bottom of $\mathrm{SS}_{2}$, thus explaining sludge resuspension events.

Eventual $\mathrm{NO}_{3}-\mathrm{N}$ concentrations below $2 \mathrm{mg} \times \mathrm{L}^{-1}$ measured in the final effluent $\left(E f_{2}\right)$ are evidence that $\mathrm{CSAS}_{\mathrm{M}}$ 's conditions can be adjusted in order to optimize denitrification process limited by a high $\mathrm{R}$ value in $R E C_{3}(98 \%)$. Even when $\mathrm{NO}_{3}{ }^{-} \mathrm{N}$ were produced in $S R_{3}$ and $S R_{4}$, the high $\mathrm{R}$ value in $R E C_{3}$ made that a high $\mathrm{NO}_{3}-\mathrm{N}$ flow to the $C R_{2}$ limited its availability in $S R_{2}$ for denitrification. Whereas denitrification was affected due to the high $\mathrm{R}$ value in $\mathrm{REC}_{3}$, this condition had a positive influence in Stage 2 performance as it controlled biomass waste, determining the $\mathrm{SRT}_{\mathrm{M}-\mathrm{S} 2}(20.9 \pm 6.7 \mathrm{~d})$. This condition promoted nitrification and high VSSML concentrations that guaranteed the system's operational stability. Results suggest that $\mathrm{R}$ value could be adjusted in order to promote denitrification in $S R_{2}$ and secure the system's operational stability

\section{Conclusions}

TAN removal efficiencies observed for the modified CSAS system $\left(\mathrm{CSAS}_{\mathrm{M}}\right)$ were significantly higher $(92 \pm 7 \%)$ compared to traditional CSAS system $\left(\mathrm{CSAS}_{\mathrm{C}}\right)$ and $\mathrm{NO}_{3}^{-}-\mathrm{N}$ concentrations in the final effluent were considerably low $\left(9.1 \pm 5.8 \mathrm{mg} \times \mathrm{L}^{-1}\right)$. This behavior suggests that the proposed modifications improved nitrogen removal processes in the $\mathrm{CSAS}_{\mathrm{M}}$. Operational conditions established in both $\mathrm{CSAS}_{\mathrm{C}}$ and $\mathrm{CSAS}_{\mathrm{M}}$ indicated that nitrification was the predominant TAN transformation process. Stage 2 helped CSAS $_{M}$ to reach higher nitrification efficiencies in comparison with CSAS, where the main nitrogen removal process in Stage 1 was denitrification, which took place especially in the anoxic compartment $\left(S R_{2}\right)$ where adequate environmental conditions for 
its occurrence were established. Finally, the $\mathrm{R}$ value in $R E C_{3}$ must be carefully evaluated in order to allow an abundant flow of $\mathrm{NO}_{3}{ }^{-} \mathrm{N}$ to $S R_{2}$ by the time that operational stability concerning VSSML must be also guaranteed.

A strong relationship between $R E C_{3}$ and $\mathrm{SRT}_{\mathrm{M}-\mathrm{S} 2}$ was found as $R E C_{3}$ controlled biomass waste from Stage 2 . The $\mathrm{R}$ value of $98 \%$ for $R E C_{3}$ promoted a high $\mathrm{SRT}_{\mathrm{M}-\mathrm{S} 2}$ average of 20.9-6.7 $\mathrm{d}$ and secured the system's operational stability in terms of SSVML concentrations, with values of $1243 \pm 412 \mathrm{mg} \times \mathrm{L}^{-1}$ in $C R_{1}$, $1393 \pm 523 \mathrm{mg} \times \mathrm{L}^{-1}$ in $C R_{2}$ and around $2500 \mathrm{mg} \times \mathrm{L}^{-1}$ in $S R_{M}$ 's compartments.

\section{References}

[1] W. Gujer and D. Jenkins, "The contact stabilization activated sludge process-oxygen utilization, sludge production and efficiency", Water Research, vol. 9, no. 5, pp. 553-560, 1975 .

[2] W. Gujer and D. Jenkins, "A nitrification model for the contact stabilization activated sludge process", Water Research, vol. 9, no. 5, pp. 561-566, 1975.

[3] N. Z. Al-Mutairi, F. A. Al-Sharifi and S. B. Al-Shammari, "Evaluation study of a slaughterhouse wastewater treatment plant including contact-assisted activated sludge and DAF”, Desalination, vol. 225, no. 1, pp. 167-175, 2008.

[4] R. Al-Sa'ed and O. Zimmo, "Process performance evaluation of the contact stabilisation system at Birzeit University", International Journal of Environment and Pollution, vol. 21, no. 5, pp. 511-518, 2004.

[5] S. N. Vásquez, V. J. Rodríguez and L. P. Torres, "Comportamiento del nitrógeno en un sistema de lodos activados en la modalidad de estabilización por contacto tratando aguas residuales domésticas”, Afinidad, vol. 67, no. 548, pp. 283-288, 2010.

[6] F. Meerburg, S. Vlaeminck, J. Vercamer and N. Boon, “Turn it up!: High-load Contact Stabilization (HiCS) is a valuable activated sludge process for maximizing sludge production from sewage", in Proc. 2nd IWA Specialist conference on EcoTechnologies for Sewage Treatment Plants (EcoSTP-2014), 2014.

[7] W. V. Alexander, G. Ekama and G. V. R. Marais, "The activated sludge process part 2. Application of the general kinetic model to the contact stabilization process", Water Research, vol. 14, no. 12, pp. 1737-1747, 1980.

[8] C. W. Randall and D. SEN, "Full-scale evaluation of an integrated fixed-film activated sludge (IFAS) process for enhanced nitrogen removal”, Water Science and Technology, vol. 33, no. 12, pp. 155-162, 1996.

[9] M. Tizghadam, C. Dagot and M. Baudu, "Wastewater treatment in a hybrid activated sludge baffled reactor", Journal of Hazardous Materials, vol. 154, no. 1, pp. 550-557, 2008.

[10] A. K. Thalla, R. Bhargava and P. Kumar, "Nitrification kinetics of activated sludge-biofilm system: A mathematical model”, BioresourceTechnology, vol. 101, pp. 5827-5835, 2010. 
[11] I. A. Hamdy, M. A. Mahmoud, S. Mohamed, O. Alaa and M. Mostafa, "The effects of modification for contact stabilization activated sludge on EBPR”, HBRC Journal, vol. 10, no. 1, pp. 92-99, 2014.

[12] APHA. Standard methods for the examination of water and wastewater, 21st ed. Washington: APHA, American Water Works Assoc. and Water Environment Federation, 2005.

[13] B. E. Rittmann and P. L. Mccarty, "Model of steady state biofilm kinetics", Biotechnology and Bioengineering, vol. 22, no. 11, pp. 2343-2357, 1980.

[14] B. E. Rittmann and J. A. Manem, "Development and experimental evaluation of a steady state, multispecies biofilm model”, Biotechnology and Bioengineering, vol. 39, no. 9, pp. 914-922, 1992.

[15] M. Fouad and R. Bhargava, "A simplified model for the steady-state biofilm-activated sludge reactor”, Journal of Environmental Management, vol. 74, no. 3, pp. 245-253, 2005.

[16] C. Grady, G. T. Daigger and H. Elm, "Biological wastewater treatment. Revised and expanded”, Environmental Science and Pollution Control Series. Marcel Dekker, 1999.

[17] Y. H. Lin, "Kinetics of nitrogen and carbon removal in a moving-fixed bed biofilm reactor”, Applied Mathematical Modelling, vol. 32, no. 11, pp. 2360-2377, 2008.

[18] H. Spanjers and P. Vanrolleghem, "Respirometry as a tool for rapid characterization of wastewater and activated sludge”, Water Science and Technology, vol. 31, no. 2, pp. 105-114, 1995.

[19] Q. Feng, Y. Wang, T. Wang, H. Zheng, L. Chu, C. Zhang and X. H. Xing, "Effects of packing rates of cubic-shaped polyurethane foam carriers on the microbial community and the removal of organics and nitrogen in moving bed biofilm reactors", Bioresource Technology, vol. 117, pp. 201-207, 2012.

[20] Metcalf and Eddy. Wastewater engineering: treatment and reuse. New York: McGraw-Hill, 2003.

[21] T. Mañunga, J. A. Rodríguez Victoria and P. Torres Lozada, "Tratamiento de agua residual doméstica sin clarificación primaria en un sistema de lodos activados en la modalidad de estabilización por contacto". Revista Científica Ingeniería y Desarrollo, vol. 30, no. 2, pp. 246-260, 2012.

[22] N. Bernet and M. Spérandio, "Principles of nitrifying processes", in Environmental technologies to treat nitrogen pollution, 1st ed. London: IWA Publishing, 2009, pp. 23-37.

[23] F. Çeçen, E. Orak and P. Gökçin, "Nitrification studies on fertilizer wastewaters in activated sludge and biofilm reactors", Water Science and Technology, vol. 32, no. 12, pp. 141-148, 1995.

[24] J. Liu, B. Wang, W. Li, C. Jin, X. Cao and L. Wang, "Removal of nitrogen from coal gasification and coke plant wastewaters in A/O submerged biofilm-activated sludge (SBF-AS) hybrid system”, Water Science and Technology, vol. 34, no. 10, pp 17-24, 1996. 